\title{
Political discourse and the study of parliamentary communication: a comparative analysis
}

\author{
Anna Konstantinova ${ }^{1}$, Svetlana Anufrienko ${ }^{1, *}$, Madina Abazalieva ${ }^{2}$, Arevik Gevorgyan ${ }^{3}$, and Elena Soloveva ${ }^{4}$ \\ ${ }^{1}$ Department of Conflict Resolution Studies, Public Relations and Journalism, Pyatigorsk State University, 9, Kalinina lane, \\ 357532, Pyatigorsk, Russia \\ ${ }^{2}$ Department of Philosophy and Humanities, North Caucasian State Academy, 36, Stavropolskaya Str., 369001, Cherkessk, \\ Russia \\ ${ }^{3}$ Department of European Languages, Pyatigorsk State University, 9, Kalinina lane, 357532, Pyatigorsk, Russia \\ ${ }^{4}$ Department of International Relations, Politology and World Economy, Pyatigorsk State University, 9, Kalinina lane, 357532, \\ Pyatigorsk, Russia
}

\begin{abstract}
The article is devoted to an analytical review of the main areas of theoretical and applied research of parliamentary communication, among which a special attention is given to the theory of political discourse and political linguistics. The prospects for a comparative study of public parliamentary communication are outlined as one of the comparatively not studied components of political discourse. Today parliamentary discourse, being one of the components of political discourse, is the subject and object of several humanitarian disciplines. The main system-forming factor of parliamentary discourse is its institutionality, which determines both the form and the content of parliamentary communication. The development of parliamentary communication as a democratic form of exercising state power is influenced by historical, social and cultural progress of mankind as a whole, and the specifics of achieving this progress in separate countries. Despite the existence of a universal democratic framework that determines the status of parliament as a social institution in different countries, its activities have national and cultural specifics. Comparison and identification of universal and national-cultural-specific language features of the parliamentary discourse in different countries are the urgent tasks for political linguistics to fulfill.
\end{abstract}

\section{Introduction}

The intensification of political life that is currently observed everywhere entails an increasing interest in the problems of political communication, which is corroborated, in particular, by numerous studies of political discourse. Among the studies devoted to the problem of political discourse are the works of $\mathrm{R}$. Boatright, J. Shaffer, S. Sobieraj, D. Goldthwaite Young, W.E. Connolly, I. Fairclough and N. Fairclough, D. Howarth, A. Norval, C. Schaeffner, A. Wieczorek, A. Musolff and others [1-7].

Applied problems of political communication related to the study of its linguistic component are revealed in numerous scientific monographs and articles on political linguistics. Characteristic features of political linguistics are anthropocentrism, functionalism, explanatory nature, which characterize the approaches presented by the works of L. Sriwimon, P.J. Zilli, U. Yaqub, S.A. Chun, V. Atluri, J. Vaidya, P. Norris and others [8-10].

As it is known, political linguistics originated in Europe. The most prominent representatives of European political linguistics are P. Chilton, J.A. Garrido Ardila, A. Albalat-Mascarell, M.L. Carrió-Pastor, M.
Temmerman, R. Moernaut, R. Coesemans, J. Mast and others [11-14].

At the present stage, political linguistics is experiencing a period of "globalization": if at earlier stages of its development, political communication was in the attention focus only of European or North American researchers, today scientists of various fields are conducting scientific work on the problem. So, in the late 20th - early 21 st century, Eastern Europe became one of the recognized research centers of political linguistics. The main research area for the linguists of this region is the study of political communication in their countries, as well as the comparison of the domestic political discourse with the political discourse of foreign countries, the analysis of new trends in this area.

For the studies in the sphere of political communication, conducted by modern representatives of Eastern European political linguistics, the following general features are characteristic:

1. Studying cognitive, discursive and rhetorical (semantic-stylistic) areas of political communication.

2. Giving preference to descriptive methods rather than to critical analysis of discourse (although in the publications of G. Lazarovici, B. Norman and some

\footnotetext{
* Corresponding author: ssidorova@list.ru
} 
other scientists, elements of critical analysis are presented to some extent) [15-16].

3. Primary interest in the study of media political discourse and a relatively small research of institutional political discourse. The general laws of political communication are studied, rather than the ideologies of certain politicians and journalists.

4. Increased attention to the study of foreign political discourse; interest in comparative studies, including the comparison of the post-Soviet states political discourse with the Soviet, Western European and American discourse.

North America is another recognized leader in the development of political linguistics (S. Franssila, A.L. Hostetler, M.A. Nee, M.L. Pratt and others) [17-19]. The characteristic features of the North American studies include:

- preference given to the study of the North American political discourse before the study of the foreign political discourses;

- studies differentiation of contemporary political discourse and discourse of past time.

Thus, specialists in the field of political linguistics are interested in both traditional and new aspects of the language, society and government interaction. Modern political linguistics as a field of scientific research is closely connected with the theory of communication, sociolinguistics, communicative linguistics, functional stylistics, text linguistics. Applied research in this area has a clearly defined interdisciplinary character and includes, along with its special methods and techniques, elements of stylistic and rhetorical linguistic analysis. Political linguistics studies the problems of language and functional style of political speech, genre features of political discourse, as well as transformations of vocabulary and phraseology, determined by the features of political communication.

\section{Materials and methods}

The main goal of this research is to identify the problems of political discourse and identify the main approaches to the study of parliamentary communication at the present stage of science development:

To achieve this goal, the authors are to:

- study the concepts of political communication in the works of leading researchers;

- explore the activities of a parliament as a political institution in different countries considering its national and cultural specifics,

- systematize the main approaches to the definition of the discourse concept;

- identify the main system-forming and constitutive features of parliamentary discourse as a part of political discourse;

- identify the factors influencing the emergence and development of parliamentary communication as a democratic form of the state power implementation;

- explore the prospects for further comparative research of the language features of parliamentary discourse in different countries.
To achieve the goal and the above-mentioned objectives of the study, the authors used comparative and descriptive methods, as well as the synthesis of cognitive linguistics and discourse analysis methods.

\section{Results and discussion}

\section{Parliamentary communication as a subject and object of the political discourse theory}

In modern political linguistics, there are several concepts of political communication. At the heart of the most popular one is cognitivism. According to the cognitivelinguistic approach, speech activity is a reflection of the world picture that exists in the mind of a native speaker, and the means of its linguistic representation can serve as material for studying national, social and individual mentality.

A significant contribution to the development of the methodology of the cognitive study of political linguistics belongs to D. Lakoff [20]. This approach allows getting from the units of discourse description to modeling the structures of political communication participants' consciousness. Within this approach, the description of the cognitive ground of political discourse becomes possible based on frame analysis and political discourse concepts modeling, identifying metaphors and stereotypes that form the base of political prejudices.

Studies in the field of political communication, carried out, on the one hand, by modern representatives of Western European and North American science, and on the other hand, by the researchers studying political communication in the post-Soviet countries, also possess some signs of "family" similarity. They are:

- more than $70 \%$ of studies performed in the cognitive research framework;

- an increase in the number of studies carried out within the rhetorical research;

- an interest in identifying ways of demonstrating citizenship and political position by communicators;

- increased attention to the study of institutional political discourse, including texts created by wellknown political leaders;

- focus on the development of cognitive-oriented metaphorical models of political communication, the basis for the identification of which is the specificity of the target spheres of metaphoric expansion;

- active use of content analysis techniques;

- an increased interest in the study of mass media political discourse;

- a relatively small amount of research on the comparative study of political communication in different countries and ages;

- the desire to synthesize methods of cognitive linguistics and discourse analysis.

As already noted, the second largest group of studies is the rhetorical political linguistics in the speech of politicians. The rhetorical research appeared much earlier than the cognitive one, but by the middle of the 20th century it had lost its popularity. With the advent of neorhetoric, a new stage begins in the study of 
phenomena, manifested in emerging expressiveness and emotions in political speech. One of the founders of the non-rhetorical study of political metaphors is Michael Osborne [21]. His work on archetypical metaphors laid the foundation for studying metaphors in the rhetorical field of political linguistics. Having studied the peculiarities of politicians' appeals to voters, Osborne found out that archetypal metaphors are invariably present in political speech (regardless of time, culture and geographical location of its producers). They include metaphorical images of light and darkness, heat and cold, illness and health. Metaphors of this kind are based on universal archetypes, which create prerequisites for political influence and persuasion, act as a pledge for understanding each other by representatives of different ethnic groups.

The third most significant and popular approach, defined as the discursive field of political-linguistic research, is implemented in two forms: in a critical analysis of political discourse and in its descriptive linguistic analysis. A special place in the critical discourse analysis is given to social, gender, ethnic inequality. The works in this field include studies of $\mathrm{H}$. Davis, D. Harp, D. Tannen [22-24]. The adjective "critical" in the designation of one of the approaches to the analysis of discourse emphasizes the recognition of a mutual relationship existing between language, power and ideology. A critical analysis of political discourse is aimed at studying the ways in which power exercises its supremacy in the society, the way in which the communicative activities of politicians reproduce social inequality. Researchers are also interested in the ways of language resistance to social inequality. The research materials include political texts created in a situation of social risks and reflecting the social inequality of communicants.

Another aspect to the critical analysis of political discourse is related to the study of the language behavior of individual politicians. The study of political discourse texts can be aimed at identifying both strategies and tactics that they knowingly use, as well as implicit and unconscious attitudes. In the process of analysis, language means, rhetorical devices and strategies that are chosen by politicians to persuade and manipulate are studied $[25,26]$.

The sociolinguistic approach to the study of political communication is also associated with the concept of social control, as a means of which the language acts. One of the theories developed by the supporters of this approach is that politicians belonging to the elite of a given society carry out their activities using a special, "political" language, thanks to the mastering of which they force the authorities to listen to their opinions and demands. Conversely, non-elite members of society do not have access to key authorities because of the limited ability to express their political opinions and demands in the appropriate language.

Another area of political discourse research, known as the "symbolic approach", focuses on studying the process of creating and distributing symbols of political power; according to the representatives of this approach, leadership in political discourse is carried out mostly through the manipulation of symbols: verbal and nonverbal.

Within the framework of the functional approach, the importance of verbal means of political communication for maintaining the stability of the political system is considered, being carried out, first of all, by the mass media. Medial political communication performs the functions of the state system stabilization and the citizens' socialization.

As for the organizational approach, the analysis of political communication focuses on information flows within the government. The government is a large bureaucratic organization, and the attention of researchers is focused on the factors that limit these flows.

Finally, the representatives of the approach, which can be conventionally called "ecological" [27], investigate the influence of the political system on political communication: the political system creates an environment in which social institutions of communication are formed and communication processes in the society are regulated.

By the beginning of the $21 \mathrm{st}$ century, political linguistics borrowed a number of research techniques from text linguistics, sociolinguistics, and sociology were. So, for the purpose of analyzing the substantive component of the texts of political discourse, a descriptive analysis and a content analysis method are used, which allow to identify the dominant values and the propensity of a particular politician for conflict or cooperation [28]. On the material of political discourse texts, a study of political metaphors is undertaken. On the material of numerous political texts devoted to a particular political event, debates, election campaigns, inaugural speeches and appeals to the nation are explored.

The interdisciplinary or integrative analysis used in the study of political discourse is based on a set of basic principles and research techniques, including the consideration of political communication texts in terms of verbal interaction and the recognition of the close connection of the political communication concept with the social control concept.

\section{Parliament as a social institution defining extralinguistic and linguistic characteristics of public parliamentary discourse}

The concept denoted by the word parliament can be interpreted ambiguously: more generally, as the concept of a social institution of a democratic society, and more specifically, as the representative legislature body concept in a particular country. L. Kissler defines parliament as a collective sender of the message, which directs its own representative actions to itself (horizontal parliamentary communication) and to the public of the represented citizens as its addressees (vertical parliamentary communication) [29]. The activities of any parliament are based on three main points typical of a given social institution: a main idea, power and consensus. 
As it is known, the country's parliament is not always the only representative body of state power. For example, in the Russian Federation there are regional parliaments (legislative bodies of the subjects of the Russian Federation) and a federal parliament (the State Duma and the Federal Assembly of the Russian Federation). In the given article, the term Parliament is used to designate the State Duma and the Bundestag the representative legislative bodies of the Russian Federation and the Federal Republic of Germany, carrying out several types of legislative activity.

Profound and comprehensive studies of history, principles of organization and fulfilling of the European parliaments' activities are presented in the works of German researchers. According to these studies, a parliament, like other social institutions, is a specific structure of a democratic society, with persons acting in it according to their obligations, with certain agreements, with specific personnel, with its own buildings and / or technical equipment. After being elected, the members of the parliament become agents of this institution as a representative body, as well as the party they represent. Within certain limits, they act objectively intentionally (which in practice does not exclude subjective actions). On the one hand, they are responsible not personally, but only institutionally. On the other hand, they are in a state of "double loyalty": in relation to the parliamentary committee, of which they are members, and the party that had elected them.

As a result - constantly emerging conflicts of loyalty, as well as a special level of responsibility, and not raised, according to some widespread views, but lowered. To designate such an institutional ("non-subjective") form of responsibility, there is a special term: political responsibility.

Parliament for itself creates the procedures and "subinstitutions" that it needs in order to fulfill its mission: to be able to make decisions as economically and efficiently as possible. In the conditions of parliamentarism, its activity is based on the principle of majority, i.e. the premise that the majority opinion is closest to the truth and the majority will make the right decisions. For the whole parliamentary procedure, the following principle is applied: "A system, that must guarantee the possibility of solving all the problems, cannot simultaneously guarantee the correctness of the decisions" [30]. It only "delivers" the decisions made by the majority. The legitimacy of the decision is not based on the majority, but on the procedure itself.

Parliament as a social institution is the result of "the process of establishment by common will" [31], which historically consists of the following: 1 . The expression of the general will regarding the intention to establish a parliament; 2. Drawing up the charter; 3 . The actual establishment of the parliament; 4. Recognition of its legal capacity.

The country's parliament serves to ensure the coexistence of its members, who are agents and at the same time clients of parliamentary speech. In a broad understanding of the parliamentary discourse, its clients are also not present directly at the parliamentary meetings and represented by members of parliament voters. Parliament creates other social institutions, such as ministries and departments, as well as their legal base, and thus organizes the society. The main task of the parliament is to establish and maintain a state of balance between various interests and forces within institutions on the one hand and in relations between institutions and the whole society on the other. Parliament's normative decisions are binding, with respect to both internal and external public. Parliament is not a social or economic institution, but a political one that in a special way governs the processes of forming opinion, will and search of the right decision in the society on the whole. G. Göhler, proposing to distinguish political institutions in a "wide" and "narrow sense", defines parliament as a political institution, which is also an executive body and a symbol of people's sovereignty [32].

Finally, parliaments, in their activities, usually proceed, in contrast to many other forms of exercising power, from certain constituent documents referring to the basic idea of democratic representation, namely from constitutions, constituent meetings and, in the case of a democratic system of government, from elections to the national assembly.

Parliament is also an institution for its members, performing a complex of regulated verbal-non-verbal actions, and the discourse carried out in it is institutional. Due to the fact that the latter concept has several definitions that are not always consistent with each other, it seems appropriate to further clarify it. The term discourse itself, as it is known, was introduced into science at the beginning of the 20th century, and the actual linguistic studies of discourse began to develop in the middle of the century. Today, it is differently understood by various researchers and is used, respectively, in different contexts. It is interpreted both as a "narrative", and as a text, generated and functioning in a certain communicative environment, and as its speech genres, and as a speech, and as a speech assigned by the speaker, and as any particular utterance, and as a statement in conjunction with a communicative situation, viewed from the discursive mechanism approach that controls it, and as a "language life", and as a system of restrictions imposed on the statement by the social or ideological position of the participants in the discourse.

Discussing this problem, M. Foucault came to the conclusion that discourse should be called "a set of statements as they belong to the same discursive formation" [33]. Discourse, therefore, is understood not as an infinite and indivisible commonality of utterances, but as a text in its dynamics, constituted by a certain number of utterances, for which it is possible to define "a set of conditions for existence". Moreover, discourse is not an ideal or timeless form with its own history.

The concept of discursive practice introduced by M. Foucault is important for understanding the essence of discourse, i.e. it is a set of anonymous historical rules of conversation, which are always defined relatively to the time and communicative space. He writes that discursive practice as a condition for the utterance function is established in a given era and for a given social, economic, geographical or linguistic space.

The term "discourse", which, in fact, has never been 
purely linguistic, is often viewed today as an attribute of any social activity and any social institutionalization. The question of discourse boundaries is rightful. It is obvious that the space of parliamentary discourse not only covers all the official activities of the parliament, but goes beyond its borders. There is a kind of an "unofficial" parliamentary process, which is associated with "backstage" political activities.

The most appropriate interpretations of discourse in the present work are its definitions as a complex communicative event, represented in the text as a verbal product of a communicative action, containing socially significant information.

The discourse of politicians and statesmen, concentrates around the supporting concept of power and creates a context that describes the actors, their actions, the objects under discussion, circumstances, time, and the place of events. Political discourse combines both public and "backstage" political speech activity of people exercising power or fighting for state power, as well as discussing political problems in the media and in the society in general [34].

We consider discourse as a process and a result of building on the basis of the initial semantic structure, or a sequence of propositions interconnected by logical relations.

Many scholars define parliamentary discourse as a part of political discourse. So, to identify the specifics of political discourse, it is necessary to take into account the following elements: stated events, their participants, performative information and "non-events", i.e. a) the circumstances accompanying the event; b) background explaining the events; c) evaluation of the events by participants"; d) information relating the discourse with the events.

Common, systematizing signs of political discourse as a generic concept and parliamentary discourse as a specific one are, above all, the communication goals of the participants. But at the same time, the goal of political discourse participants can be both conquest and struggle to retain state power, while in parliament state power is directly exercised through legislative activity.

During the plenary sessions, the parliamentary discourse is carried out in accordance with clearly established and strictly followed regulations. Discussion of the agenda issues at parliamentary meetings in the State Duma of the Russian Federation and the German Bundestag is determined by the regulations of these institutions - the parliamentary statute or protocol, the general law and custom. The agenda of the plenary meeting is approved in advance, and during the meeting can be changed only after a decision is made on this by voting. The content of the reports and speeches of the deputies, as well as the right to speak at the plenary session and to participate in the debate are discussed in advance - during the meetings of parliamentary committees and factions. It makes public parliamentary discourse different from public political discussions accompanying election campaigns.

The main backbone indicator of parliamentary discourse is its institutionality. A. Chudinov and $\mathrm{O}$. Solopova understand institutional discourse as implemented in public institutions, in which the methods and means of communication are an integral part of their organization [35].

The institutional discourse represents communication within the framework of institutions established in the society, that is, stable complexes of formal and informal rules, principles, norms, attitudes that regulate various spheres of human activity and organize them into a system of roles and statuses that form the social system.

The constitutive features of discourse include participants, conditions, organization, methods and material of communication, i.e. people in their status and situational-communicative roles, communication and its environment, motives, goals, strategies, channels, mode, tonality, style and genre of communication and, finally, a significant body of communication (texts and / or nonverbal signs). M.L. Makarov notes that institutional discourse has a rigid structure, a maximum of speech restrictions, characterized by the primacy of a global organization that regulates the communication of roles and a limited number of globally defined goals. Compared with colloquial discourse, it is less conditioned by the immediate context [36].

Along with the backbone institutional discourses have neutral signs. In contrast to system-forming signs, neutral ones are understood as general discursive characteristics inherent to any communication, as well as personality-oriented signs of the participants.

The concept of institutional discourse is associated with a certain number and functions of its participants, with specific spaces and structures in which they perform these functions and where there are certain social rituals and behavioral stereotypes. In addition, in each discourse special, specific texts are also produced. The signs of parliamentary discourse institutionalism are fixed by the role characteristics of its participants agents and clients of the parliament as one of the public institutions, typical chronotopes, symbolic actions, stereotyped genres and speech clichés. It is the stencil of communication that fundamentally distinguishes institutional discourse from personal discourse.

There are several approaches to describing the specifics of speech communication in institutional discourses. As noted by V.I. Karasik, communication in institutional discourses, including the State Duma of the Russian Federation, is determined by the presence of mandatory components of speech situations [34]. In the studies devoted to the Russian parliamentary discourse, these approaches include "institutional voices" and strategies of participants in the discourse, their goals, values and key concepts, the discourse chronotope, its subject, genres and types of genres used, precedent (cultural) texts and, finally, institutional discursive formulas. Political communication in Germany, including the Bundestag, is generally described similarly by foreign authors. The main participants in the parliamentary discourses of the Russian Federation and the Federal Republic of Germany are members of parliament - deputies (agents) and people who endow them with this role (clients). According to German and Russian researchers, the main components of the speech 
situation of parliamentary communication are: a member of parliament; space; time; the purpose of the address.

The key concept of parliamentary discourse in both cases is the concept of power. However, there are certain differences. Thus, the components of parliamentary communication speech situations by German researchers can be represented as follows: a regulation; a president; parties and factions; listeners; parliamentary traditions; situational context.

Thus, the main components of parliamentary communication situations in Russia and Germany are repeated, although they are detailed in various degrees and are not always evaluated as equally significant. For example, D. Allhoff emphasizes the situational context, which in parliamentary discourse, unlike the key concept of power, changes from speech to speech [37]. Each previous statement may introduce a new topic and influence the speech situation in which the next one is carried out. D. Allhoff demarcates parliamentary members ("internal addressee") and listeners ("external addressee") and includes parliamentary traditions as components of the speech situation, while V. Karasik pays special attention to the themes and key concepts, speech strategies, genres and types of genres, precedent (cultural) texts and discursive formulas.

It is easy to see that according to D. Allhoff's views, many of these points can be summarized in the concept of a situational context which is characteristic of the activities of a given social institution.

\section{Conclusion}

Nowadays, the problems of political linguistics are noted in general and at the same time studied to different degrees. The constant appeal of researchers to all the new aspects of political communication and the variety of approaches and methods of studying it testifies to the relevance of this problem and requires its comprehensive understanding.

A comparative study of the political discourses of different countries and ages is especially relevant and having undoubted prospects due to the specifics of the changes that take place in the period of democratization in political life in general and in the activities of public institutions - in particular, under the influence of sociocultural factors. Thus, in comparative terms, the peculiarities of Russian-speaking and German-speaking public parliamentary speech were not studied. Such comparison makes it possible to clearly differentiate between "one's own" and "someone else's" opinions, random and regular events, universal and peculiar phenomena, characteristic of some national discourse.

Summarizing the study, we can draw the following main conclusions:

1. The key discourse-forming concept, verbalized in public parliamentary discourse, is the concept of power. The verbal realization of the powers of the parliament members presupposes the public presentation and coordination of the positions of the participants in the parliamentary discourse - the search for a generally acceptable or optimal solution - a compromise.
2. The emergence and development of parliamentary communication as a democratic form of state power exercising is due, on the one hand, to the historical, social and cultural progress of all mankind, and on the other hand, to the peculiarities of achieving this progress in each individual country.

3. If there is a universal democratic framework that determines the status of parliament as a social institution and as an instrument of government in different countries, its activity does not exclude national-cultural specifics, which can be corroborated by comparative linguistic and stylistic analysis of relevant practical material.

4. Comparative study and identification of universal and national-cultural-specific linguistic features of parliamentary discourse in different countries is one of the urgent problems of political linguistics.

\section{References}

1. R.G. Boatright, T.J. Shaffer, S. Sobieraj, and D. Goldthwaite Young, A crisis of civility?: political discourse and its discontents (Oxford University Press, Oxford, 2019)

2. W. Connoly, The terms of political discourse (Princeton University Press, Princeton, 1993)

3. I. Fairclough, N. Fairclough, Political discourse analysis: a method for advanced students (Routledge, London, 2013)

4. D. Howarth, A.J. Norval, Discourse theory and political analysis: identities, hegemoni (Manchester University Press, Manchester, 2000)

5. C. Schaeffner, Political discourse, media and translation (Cambridge Scholars Publishing, Cambridge, 2010)

6. A.E. Wieczorek, Clusivity: a new approach to association and dissociation in political discourse (Cambridge Scholars Publishing, Cambridge, 2013)

7. A. Musolff, Political metaphor analysis: discourse and scenarios (Bloomsbury Academic, London, 2016)

8. L. Sriwimon, P.J. Zilli, Kasetsart J. of Social Sciences, Applying critical discourse analysis as a conceptual framework for investigating gender stereotypes in political media discourse, 38, 136-142 (2017)

9. U. Yaqub, S.A. Chun, V. Atluri, and J. Vaidya, Government Information Quarterly, Analysis of political discourse on twitter in the context of the 2016 US presidential elections, 34(4), 613-626 (2017)

10. P. Norris, A virtuous circle: political communications in postindustrial societies (Cambridge University Press, Cambridge, 2013)

11. P. Chilton, J. of Language and Politics, "The people" in populist discourse: Using neuro-cognitive linguistics to understand political, 16(4), 582-594 (2017) 
12. J.A. Garrido Ardila, J. of Pragmatics, Impoliteness as a rhetorical strategy in Spain's politics, 140, 160-170 (2019)

13. A. Albalat-Mascarell, M.L. Carrió-Pastor, J. of Pragmatics, Self-representation in political campaign talk: A functional metadiscourse approach to selfmentions in televised presidential debates 147, 86-99 (2019)

14. M. Temmerman, R. Moernaut, R. Coesemans, and J. Mast, Context and Media, Post-truth and the political: Constructions and distortions in representing political facts, Discourse, 27, 1-6 (2019)

15. G. Lazarovici, Social and Behavioral Sciences, The effects of globalization upon the paradigm of the contemporary political discourse, 63, 58-62 (2012)

16. B. Norman, M. Mukhin, Sibirskii Filologicheskii Zhurnal, Lexical and grammatical semantics: $A$ corpus-based statistical study of lexical semantic group, 3, 178-191 (2018)

17. S. Franssila, Social and Behavioral Sciences, Sell Metaphors in American political news discourse, 95, 418-424 (2013)

18. A.L. Hostetler, M.A. Nee, The J. of Social Studies Research, Difficult discourses: How the distances and contours of identities shape challenging moments in political discussions, 42(4), 361-373 (2018)

19. M.L. Pratt, Language Sciences, Aesthetics, politics, and sociolinguistic analysis, 65, 18-25 (2018)

20. G. Lakoff, Instrumental adverbs and the concept of deep structure, foundations of language 4(1), 4-29 (1968).

21. M. Osborn, Michael Osborn on metaphor and style (Michigan State University Press, East Lansing, 2018)

22. H. Davis, , Language and Communication, Gender, discourse and gender and discourse 17(4), 353-357 (1997)

23. D. Harp, Gender in the 2016 US Presidential Election: Trump, Clinton, and Media Discourse (Routledge, London, 2019)
24. D. Tannen, Gender and Discourse (Oxford University Press, Oxford, 1996)

25. D. Liu, L. Lei, Discourse, Context and Media, The appeal to political sentiment: An analysis of Donald Trump's and Hillary Clinton's speech themes and discourse strategies in the 2016 US presidential election, 25, 143-152 (2018)

26. B.C. Parekh, Colonialism, tradition and reform: an analysis of Gandhi's political discourse (SAGE Publications Pvt. Ltd, New Delhi, 1999)

27. E.U. Sheigal, The semiotics of political discourse (Peremena, Volgograd, 2000)

28. P. Chilton, Analysing political discourse (Routledge, London, 2004)

29. L. Kissler, Die Öffentlichkeitsfunktion des Deutschen Bundestages: Theorie, Empirie, Reform (Duncker and Humblot, Berlin, 1976)

30. N. Luhmann, Legitimation durch Verfahren (Suhrkamp, Berlin, 2001)

31. M. Hauriou, Die Theorie der Institution und Zwei andere Aufsätze (Duncker \& Humblot, Berlin, 1965)

32. G. Göhler, Grundfragen der Theorie Politischer Institutionen (VS Verlag für Sozialwissenschaften, Opladen, 1987)

33. M. Foucault, The Archaeology of knowledge (Routledge, London, 2002)

34. V. Karasik, Discourse manifestation of personality, Russ. J. of Linguistics 20, 56-77 (2016)

35. A.P. Chudinov, O.A. Solopova, Social and Behavioral Sciences, Linguistic political prognostics: models and scenarios of future, 200, $412-417$ (2015)

36. M.L. Makarov, Basic concepts of discourse analysis (Gnozis, Moscow, 2003)

37. D. Allhoff, Rhetorische Analyse der Reden und Debatten des Ersten Deutschen Parlamentes von 1848/49. Insbesondere auf Syntaktischer und Semantischer Ebene (Tuduv-Verlagsgesellschaft, München, 1975) 